\section{GEOLOGIC REQUIREMENTS FOR EXPLOITABLE FOSSIL FUEL AND GEOTHERMAL ENERGY RESOURCES}

by James G. Clough, Paul L. Decker, Ken Helmold, and Christopher J. Nye

\section{INTRODUCTION}

Fossil fuel resources come from a variety of geologic sources, including coal, conventional oil and natural gas, and unconventional natural gas. Unlike fossil fuels, geothermal energy comes from heat in the Earth's interior and is considered a renewable resource. In order for any of these energy sources to be present in a region as an exploitable resource, specific geologic features must be present. If any of the features required for a particular energy category are missing in a region, then that resource is considered to be not present in that region. The term 'exploitable' as used here means that the resource is present in sufficient quantities that it could be used as an energy source for local communities given currently available technology. This definition does not factor in the economics of developing a resource for local consumption. A resource may be present in an area, but the cost to develop might be too high compared to alternative energy sources. Alternatively, a fossil fuel resource may be present in an area and the economics of its use might be favorable enough to render other potential energy resources less attractive economically.

The purpose of this chapter is to outline the geologic requirements for exploitable fossil fuel and geothermal resources. The economic and environmental costs of each energy category are beyond the scope of this chapter. The chapter concludes with an outline of the geologic requirements for an exploitable geothermal energy resource.

In this report, we divide fossil fuel types into two categories: Conventional fossil fuels and unconventional fossil fuels. Conventional fossil fuel categories covered include coal and conventional oil and gas. Coal must be mined using underground or surface strip-mining techniques. Conventional oil and gas resources are hydrocarbons that will flow to extraction wells without having to make dramatic changes to either the reservoir rock or reservoir fluids.

Unconventional oil and gas resources require either massive stimulation to create permeable conduits (tight gas sands and shale gas), thermal or chemical treatments to reduce oil viscosity (heavy oil and tar sands), or dewatering to promote the relative permeability of gas (coalbed methane). Unconventional fossil fuel categories covered include tight gas sands, shale gas, coalbed methane, and methane hydrates. Tar sands, or heavy oil deposits, share the same geologic requirements as conventional oil, but the viscosity is significantly higher than that of oil. Tar sands are not addressed in this chapter or this review, as there are no known exploitable occurrences of these resources in Alaska.

\section{GEOLOGIC REQUIREMENTS FOR EXPLOITABLE COAL RESOURCES}

\author{
by James G. Clough
}

Coal is a brownish-black to black combustible organic sedimentary rock formed by the decomposition of plant material, typically in a swampy or boggy environment (fig. A1). This organic material, called peat, is buried, compacted, and hardened over millions of years. This process is called coalification. During coalification, peat undergoes several changes as a result of bacterial decay, compaction, heat, and time. Peat deposits are quite varied and contain everything from pristine plant parts (roots, bark, spores, etc.) to decayed plants. The coalification of peat passes progressively through four main phases of coal development: lignite, subbituminous coal, bituminous coal, and anthracite. These end products are composed primarily

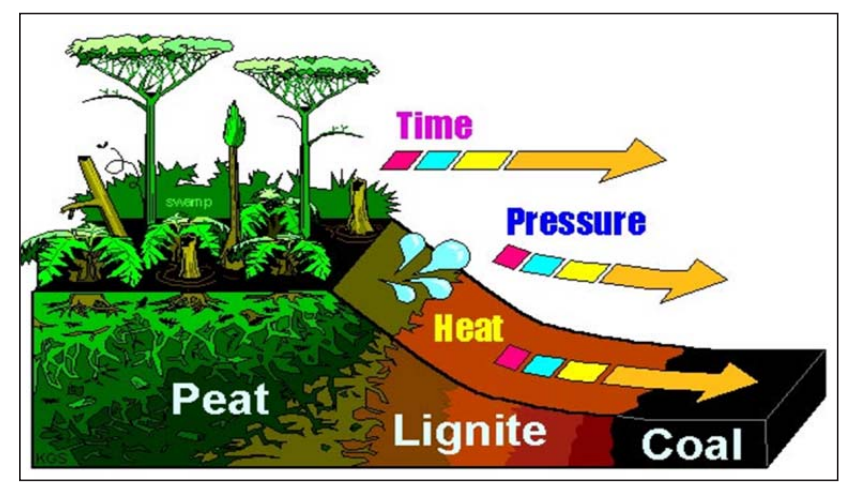

Figure A1. Diagram showing the steps in the formation of coal (Kentucky Geological Survey, 2006).

of carbon, hydrogen, oxygen, and some sulfur along with water moisture and non-combustible ash (table A1). The rank of coal is based on the amount of carbon and volatiles (water and gas) in the coal, as well as the energy content of the coal. The amount of energy in coal is expressed in British thermal units (Btu) per pound. The higher a coal's rank, the greater its heating value (table A1).

Alaska coal formed in widespread deltaic, lacustrine (lake), and alluvial (river flood plains) depositional systems. Coals that formed in delta systems tend to be laterally extensive, whereas coals that formed in river floodplain settings tend not to be as laterally continuous. In Alaska, most of the coals originating in river floodplains tend to be younger than deltaic coals, tend to be of lower rank, and formed in sedimentary basins bounded by complex fault systems that controlled basin formation and influenced peat deposition by differential subsidence (settling or sinking of the land surface over time at different rates in different areas). The main coal areas in Alaska are shown in figure A2 (Merritt and Hawley, 1986) and include the North Slope (subbituminous 
Table A1. Table showing important components of coal and heating value by rank. Modified from table in Bowen and Irwin, 2008.

\begin{tabular}{|c|c|c|c|c|}
\hline \multicolumn{4}{|c|}{ Components and Heating Value of Coal by Rank } \\
\hline$\%$ weight & Anthracite & Bituminous & $\begin{array}{c}\text { Sub- } \\
\text { Bituminous }\end{array}$ & Lignite \\
\hline $\begin{array}{c}\text { Heat Content } \\
\text { (Btu/b) }\end{array}$ & $13,000-15,000$ & $11,000-15,000$ & $8,500-13,000$ & $4,000-8,300$ \\
\hline $\begin{array}{c}\text { Moisture } \\
\text { Fixed Carbon }\end{array}$ & $85-98 \%$ & $45-85 \%$ & $35-45 \%$ & $25-35 \%$ \\
\hline Ash & $10-20 \%$ & $3-12 \%$ & $\leq 10 \%$ & $10-50 \%$ \\
\hline Sulfur & $0.6-0.8 \%$ & $0.7-4.0 \%$ & $<2 \%$ & $0.4-1.0 \%$ \\
\hline
\end{tabular}

has published 'standards' for determining 'mineable' coal resources that are based on coal bed thickness related to coal rank and the depth of the overburden for both surface mining and underground mining methods. Overburden is non-coal material that lies above the coal and must be stripped away to extract the coal using surface mining methods or to drive a mine shaft through to extract the coal by underground mining methods. Beds of higher rank bituminous and anthracite coal should be 14 inches or greater to be considered a coal resource. Lower rank lignite and bituminous coal should be $2 \frac{1}{2}$ feet to bituminous coal), Yukon-Koyukuk (subbituminous coal), Interior-Healy area (mostly subbituminous), southcentral Cook Inlet to Matanuska Valley (subbituminous to bituminous coal), Alaska Peninsula (lignite and bituminous coal), and Gulf of Alaska-Bering River area (bituminous coal to anthracite). There are numerous smaller occurrences of coal around Alaska that have small quantities of noneconomic coal. With a few exceptions, most Alaska coal is very low in sulfur, in many cases containing less than 0.5 percent, and contains low concentrations of metallic trace elements and nitrogen. These characteristics make Alaska's coals favorable for meeting environmental constraints on combustion in power plants.

\section{Coal resources are} defined as naturally occurring concentrations or deposits of coal in the Earth's crust, in such forms and amounts that economic extraction is currently or potentially feasible. What constitutes an exploitable coal resource? This is a difficult question to provide a single answer as it is based on the current economics of extracting, transporting, processing, and marketing the coal for the end user. Generally, the question can be stated, "Is the cost of mining the coal and delivering it to the user less than the price of delivered diesel/heating fuel, using the current technology for extracting coal?" The U.S. Geological Survey

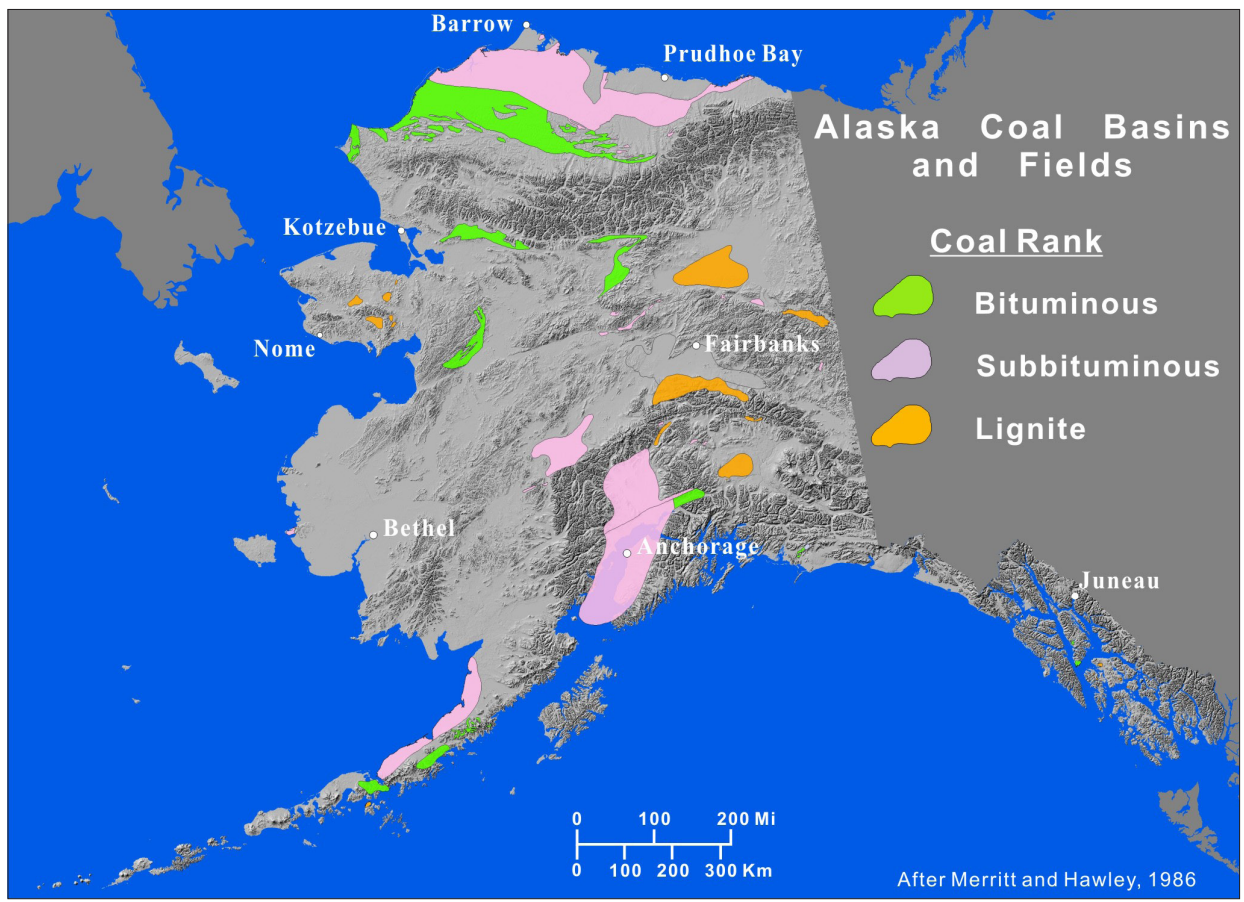

Figure A2. Map of Alaska showing the distribution of coal-bearing sedimentary basins. or thicker to be considered a coal resource. Overburden for surface mining should be 500 feet or less and is generally less than 300 feet in the U.S. Coal that is too impure, too thin, too deep, or for other reasons not considered to be potentially economic, is not classified as a resource but is classified as an other occurrence (Wood and others, 1983). Other factors must also be considered when deciding if a coal occurrence is exploitable, including the lateral extent of the coal seam or seams and the position of the coal relative to surface water bodies and groundwater.

Coal mining regulations are very precise and strict for safety and environmental purposes. A description of the 
State of Alaska Coal Regulatory Program and the specific regulations for coal mining in Alaska can be downloaded from this website: http://dnr.alaska.gov/mlw/mining/coal/ index.htm. It seems unlikely that any coals in rural areas of the state would be mined by underground methods for safety issues alone, without even considering the much higher cost of extracting coal from underground mining operations. The most common surface mining method for coal is strip or area mining. Strip mining exposes the coal by removing the overburden in long cuts or strips by excavator or shovel.

\section{GEOLOGIC REQUIREMENTS FOR EXPLOITABLE CONVENTIONAL OIL AND GAS RESOURCES}

by Paul L. Decker

For the purposes of this resource inventory, conventional oil and gas resources are hydrocarbons that will flow to extraction wells without first having to make dramatic changes to either the reservoir rock or the reservoir fluids. This distinguishes them from various unconventional oil and gas resources, which may require massive reservoir stimulation to create permeable conduits (tight gas sands, shale oil, and shale gas), thermal or chemical treatments to reduce oil viscosity (heavy oil and tar sands), or dewatering to promote the relative permeability of gas (coalbed methane). The formation of conventional hydrocarbon accumulations hinges on a series of crucial geologic processes unfolding in the proper sequence over millions or, in some cases, hundreds of millions of years. When all the necessary components are present, effective, and have had the proper interactions, they are said to make up a conventional petroleum system (Magoon and Dow, 1994).

Alaska is an amalgamation of diverse geologic provinces that have had very different geologic histories. Some settings, such as the North Slope and Cook Inlet, hosted all the processes needed to generate rich fossil-fuel resources. Conditions across much of the rest of Alaska are known to have been less favorable; certain elements of the petroleum system are either missing or they developed in the wrong sequence, ruling out the presence of conventional oil and gas resources. Finally, there are portions of the state where subsurface exploration has not yet determined whether conventional hydrocarbon resources may someday be produced commercially, or could help satisfy rural energy demand. This section describes the four basic elements of conventional petroleum systems - source, reservoir, trap, and seal - and their roles in giving rise to conventional oil and gas accumulations.

Oil source rocks (usually black shales or limestones) contain elevated levels of organic molecules rich in carbon and hydrogen that, when heated slowly to the right temperature (typically greater than about 212 degrees Fahrenheit [212oF; $>100$ degrees Celsius, $100 \mathrm{oC}]$ ), react to form the mix of chainlike hydrocarbon molecules we call crude oil. The part of a basin that is buried deeply enough to cause this thermal conversion is called 'the kitchen.' With continued burial and increased heating of 'the kitchen' (above about $\left.300^{\circ} \mathrm{F}\left[150^{\circ} \mathrm{C}\right]\right)$, these same rocks generate less oil but expel increasing amounts of the lighter, smaller hydrocarbon molecules (mainly methane) that make up natural gas. Source rocks that start out rich in carbon but leaner in hydrogen (including coals as well as many shales and limestones) can generate natural gas but not the more hydrogen-rich liquid hydrocarbons.

Apart from the thermally driven maturation that accompanies deep burial, natural gas can also be created in low-temperature $\left(175^{\circ} \mathrm{F}\left[<80^{\circ} \mathrm{C}\right]\right)$ environments by bacterial decay of coal or peat beds. If this biogenic gas forms at or very near the surface, it commonly bubbles away into the atmosphere. However, if it originates at greater depths, the gas may dissolve into the waters surrounding it and remain trapped in the source coal unless subsequent uplift reduces the pressure and allows gas to break out of solution to form a separate vapor phase. Whether of thermogenic or biogenic origin, once oil or gas exists as a liquid or vapor phase separate from the surrounding pore waters, buoyancy quickly drives the hydrocarbons to migrate from the source area, following the path of least resistance through the most permeable strata they encounter.

Conventional reservoir rocks are porous, permeable formations that can store oil and gas in the pore spaces between grains and later allow them to flow out of the rock into wellbores, where they can be recovered. Some of the most efficient petroleum systems have high-quality reservoir formations that closely overlie the source rock unit and serve as conduits for hydrocarbons migrating up and out of the 'kitchen' area toward traps closer to the basin edge. Only where these porous, permeable rocks are enclosed in trapping geometries do hydrocarbons stop migrating and accumulate in the reservoir rock to form conventional oil or gas accumulations. The quality of a reservoir depends on several variables, notably its porosity (expressed as a percentage of the total rock volume), permeability, thickness, uniformity, continuity, and hydrocarbon saturation. These factors govern both the recoverable volume of hydrocarbons contained per unit area, and the rate at which oil and gas can be produced.

Effective traps consist of reservoir rock layers overlain and/or laterally bounded by impermeable seal rock, and are of two basic types. Structural traps occur where the rock layers are deformed by folding or faulting to form concavedownward shapes capable of containing buoyant fluids such as oil and gas. Stratigraphic traps occur where porous, permeable reservoir rocks are encased in impermeable seal rocks as a result of non-uniform deposition of sediments. For example, clean sands on a wave-worked beach may grade laterally into a muddy offshore setting, and with time, the 
muddy offshore zone may migrate over the older beach sand, setting up a possible future stratigraphic trap. Structural traps are usually much easier to identify and generally host the initial oil and gas discoveries in a given basin. Stratigraphic traps are much harder to target, and their successful prediction normally requires more detailed mapping of the subsurface geology. This might be based on either an abundance of previously drilled wells or advanced processing and interpretation of high-quality three-dimensional seismic data. In any case, for traps to host oil and gas fields, they must be created prior to hydrocarbon generation, expulsion, and migration from 'the kitchen.' Additionally, they must then remain intact, uncompromised by later folding, faulting, or excessive burial.

What determines whether a conventional hydrocarbon accumulation can be exploited depends on numerous geologic and economic factors, including the type of hydrocarbon, producible rate, recoverable volume, development cost, and location. In rural Alaska, either oil or gas resources would be attractive if they could provide energy at a full-cycle cost competitive with currently subsidized deliveries of diesel fuel.

\section{GEOLOGIC REQUIREMENTS FOR UNCONVENTIONAL FOSSIL FUEL RESOURCES}

by Ken Helmold and

James G. Clough

\section{Coalbed Methane}

Coalbed methane is a cleanburning fuel that is comparable in heating value $(\sim 1,000 \mathrm{Btu} / \mathrm{scf})$ to conventional natural gas. The production of coalbed methane in the lower 48 states from coal seams accounts for about 10 percent of the gas production in the United States. Coal is one of the most abundant nonrenewable energy sources in the world, and Alaska has substantial coal resources in a number of sedimentary basins (refer to the description of exploitable coal in this chapter for more information on the origin of coal). The majority of Alaska's coal is located on the North Slope, followed by the Cook Inlet region, Interior Alaska (mainly Healy), the Alaska Peninsula, Copper River basin, and numerous smaller basins and individual coal localities throughout the state (fig. A2). Within these coal basins there must exist a number of necessary and complex geologic conditions to both generate coalbed methane and to store the gas in an underground reservoir for any possibility of exploiting this potential resource.

Unlike conventional natural gas, in coalbed methane the coal serves as both the source rock and the gas reservoir. Methane (when accompanied by water, nitrogen, and carbon dioxide) is formed when buried plant material is converted into coal over millions of years by heat, pressure, and chemical processes. This coalification process generates methane-rich gas, which often is held in pores and fractures in the coal reservoir and adsorbed to (attached to the surface of) coal particles. As a reservoir, coal is a microporous, carbonrich mineral capable of holding large quantities of gas that is generated internally. However, gas cannot be extracted from the coal reservoir unless these small micropores are connected through a well-developed fracture system called coal 'cleats' (fig. A3). Fracture permeability is the measurement of how well a fluid or gas moves through a rock when the pores are connected through a cleat or fracture system. Even if there is sufficient coalbed gas, it cannot be produced if there are very few fractures, which results in low permeability.

Importantly, coals must also reach a certain critical threshold of thermal maturity or "coal rank" before very large volumes of thermogenic methane gas is generated (fig. A4). Lower-rank lignite to subbituminous coals contain mostly biogenic gas that results from bacterial action on

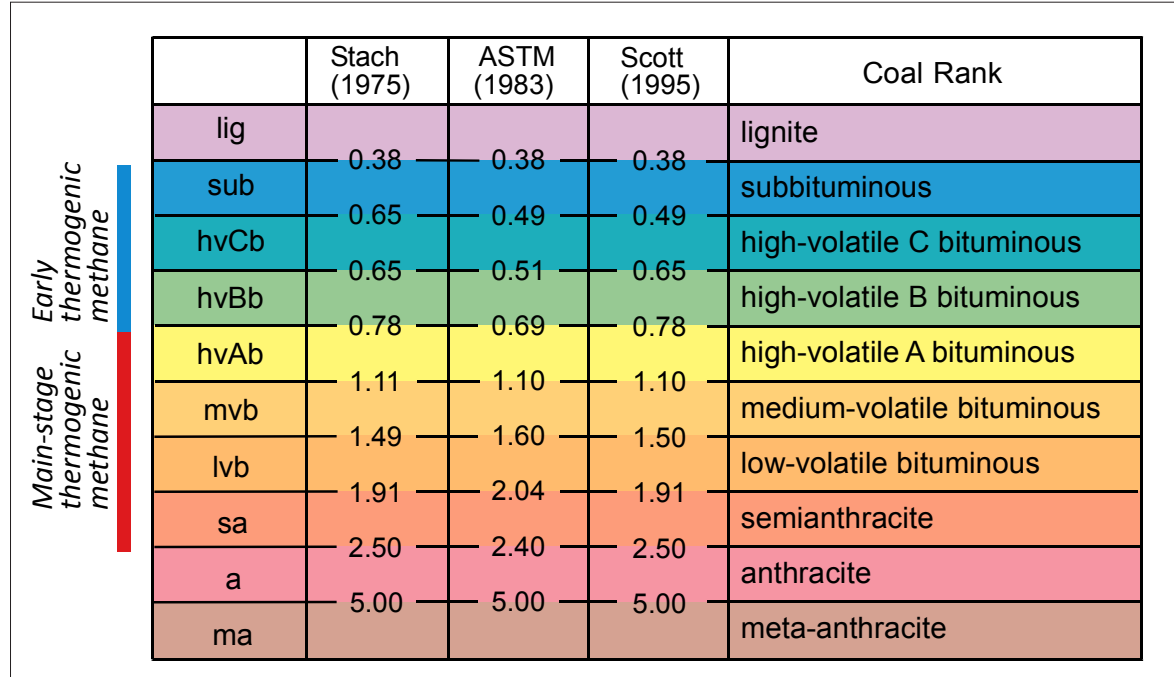

Figure A3. Coal rank. The numbers in the columns refer to rank as determined by vitrinite reflectance. Significant coalbed methane generation does not occur until the high-volatile A bituminous rank is reached. Modified from figure 15 in Scott, 2004. organic material, in the same manner methane is generated by bacteria in shallow garbage landfills. It is important to note that there is no current production of biogenic gas from lignite coals because they lack a well-developed natural fracture system. Production of biogenic gas from very thick (50 to 200 feet thick) subbituminous coals is occurring in the 


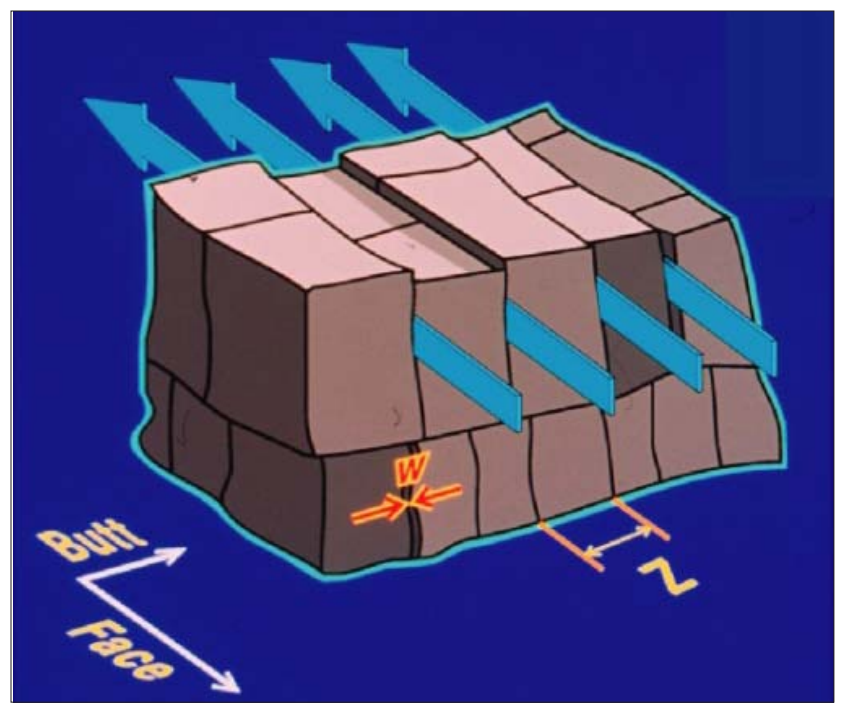

Figure A4. Schematic diagram of an intersecting network of fractures or cleats in a coal seam. While coal has porosity, the pore network is not interconnected, resulting in very low matrix permeability. Cleats provide the permeability required to produce coalbed methane. Modified from figure 4, in Scott, 1999.

Powder River Basin in Wyoming, where gas contents are, on the average, less than 35 cubic feet per ton of coal. However, most commercially-viable coalbed methane production is from coals within the range of high-volatile A bituminous to low-volatile bituminous. Coals of this rank provide both the optimum gas content (as much as 800 cubic feet of gas per ton) and well-developed natural fracture cleat systems to provide a pathway to the well bore.

Finally, coal seams are usually saturated with water, with the hydrostatic pressure keeping the methane within the coal. Sufficient hydrostatic pressure must be present throughout the geologic history of the coal seam for gas to be retained. If pressure is reduced sufficiently by erosion, uplift, or other means, gas can escape from the coal, leaving little or no gas to extract.

The usual method of producing methane from coal is to pump water from a coalbed methane production well, reducing the hydrostatic pressure and causing the methane to desorb (detach from coal particles) and begin to flow from the coal to a pumping well. A key factor in the production of coalbed methane is the fracture permeability of the coal seam. The coal must have well-developed cleats to allow the gas to flow in large quantities from the coal to the producing well. At first, coalbed methane wells produce mostly water, but over time and under proper geologic conditions, the amount of water declines and gas production increases as the bed is dewatered (fig. A5). Water removal may continue for several years. Given that coalbed methane production usually involves significant water production, there must be some way to dispose of the fluid, especially if it does not meet strict EPA water quality standards. Alaska's cold temperatures and permafrost pose significant challenges for disposal of the water by-product. In the Lower 48, produced water is either surface disposed in large evaporation ponds, surface discharged into existing bodies of water, or re-injected into deep disposal wells, depending on the chemistry of the water. Each of these disposal methods presents significant challenges in Alaska arctic and sub-arctic conditions.

A developed coalbed methane well field consists of production wells, gathering lines, separators, compressors, and water disposal facilities. In each development, water and gas from each well site are transported to a single processing site serving water disposal, gas treating, and central compression and distribution pipelines.

\section{Tight Gas Sands}

For purposes of this inventory, 'tight gas resources' are defined as hydrocarbons present in low-permeability reservoirs that produce mainly dry gas. Dry gas is natural gas that occurs in the absence of liquid hydrocarbons. A large proportion of these low-permeability reservoirs are sandstone, but limestones and dolomites also have the potential to yield producible quantities of gas. Tight gas resources are distinguished from conventional oil and gas resources in requiring massive reservoir stimulation to create permeable conduits (similar to shale gas) or dewatering to promote the relative permeability of gas (similar to coalbed methane) (Holditch, 2006). They are similar to conventional oil and gas in requiring the presence of an organic-rich, thermally-mature petroleum source rock and a reservoir rock capable of being charged with gas from the source rock (refer to the section on conventional oil and gas for an explanation

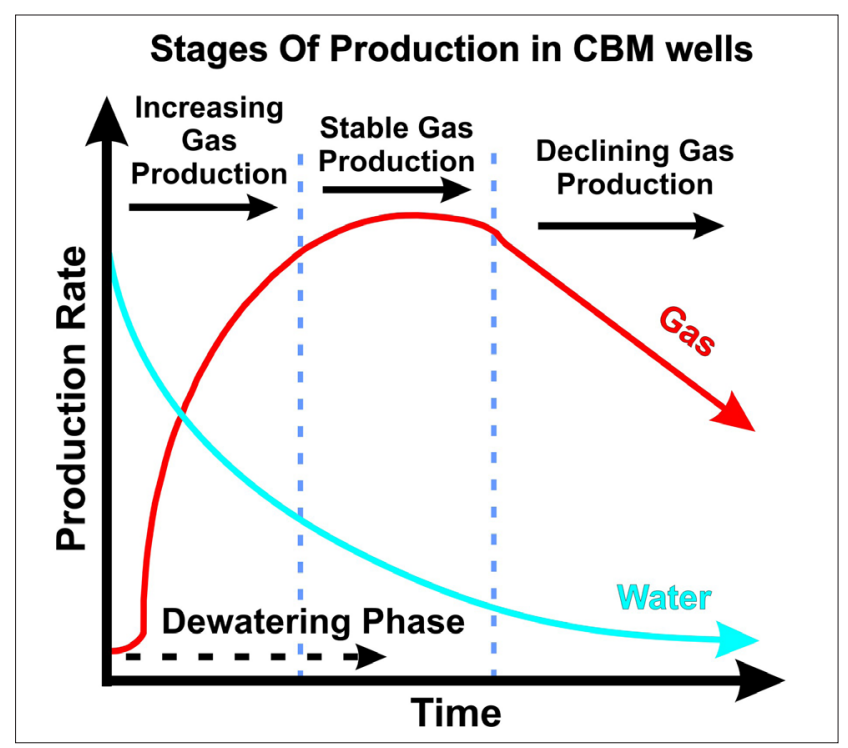

Figure A5. Generalized graph showing the relative proportions of gas and water produced from a coalbed methane well over time. Modified from Schraufnagel (1993). 
of source rocks). Stimulation involving a large hydraulicfracture treatment is usually necessary to create fracture permeability to allow the reservoir to yield commercial gas-flow rates and produce commercial quantities of gas. In fractured reservoirs (naturally fractured or stimulated), the drilling of horizontal wells may dramatically improve producibility over more traditional vertical wellbores, as horizontal wells tend to intersect a greater number of fractures than vertical wells. Tight gas reservoirs produce less gas over a longer period of time compared to conventional reservoirs. Because of this, more vertical wells or long horizontal wells must be drilled in tight reservoirs to produce commercial rates and volumes of gas. Hence, development costs are commonly higher than in conventional gas reservoirs.

Tight gas reservoirs are quite varied in their geological and engineering characteristics and as such there is no typical or ideal example. Characteristics common to all tight reservoirs include: reservoirs that tend to have large areal extents and consist of interlayered, fine-grained sedimentary rocks, commonly sandstones and mudstones, with low permeabilities; have pore networks that are partially or completed filled with gas; have a large percentage of pores that are not interconnected, or have exceedingly small connections that impede, or block, the flow of gas (low permeability); contain gas that was derived from thermally-mature source rocks, as in conventional gas reservoirs; or will not produce gas unless the permeability of the reservoir is increased through massive stimulation efforts that commonly involve the creation of fractures in the reservoir. While some tight gas reservoirs are found at relatively shallow depths, most are located at substantially greater depths of burial, approaching 15,000 to 20,000 feet in many sedimentary basins (Naik, 2007).

Exploration for tight gas sands differs from conventional reservoirs in that they generally extend over much larger areas and consist of interlayered strata of differing physical properties whose pore networks are saturated or partially saturated with gas. Conventional reservoirs have more limited boundaries, including a down-dip water contact, which is absent from continuous reservoirs (Naik, 2007). The downdip water contact in conventional reservoirs results from the lower density of oil and gas relative to water. The vast majority of continuous reservoirs are charged with gas rather than crude oil.

Exploration for, and production from, tight reservoirs requires thorough knowledge of the local geology. Important parameters that must be known include the stratigraphic distribution of source rocks and tight reservoirs in a basin, the physical and chemical characteristics of the gas source and reservoir rocks, the textural properties and grain composition of the reservoir rocks, and the fracture density in the reservoir rocks. It is also important to have some understanding of the regional geothermal and pressure gradients in the basin containing the tight reservoirs. Because of the low permeability nature of these reservoirs and the depth range at which they tend be located in sedimentary basins, the cost of developing tight gas reservoirs tends to be higher than conventional gas reservoirs (fig. A6).

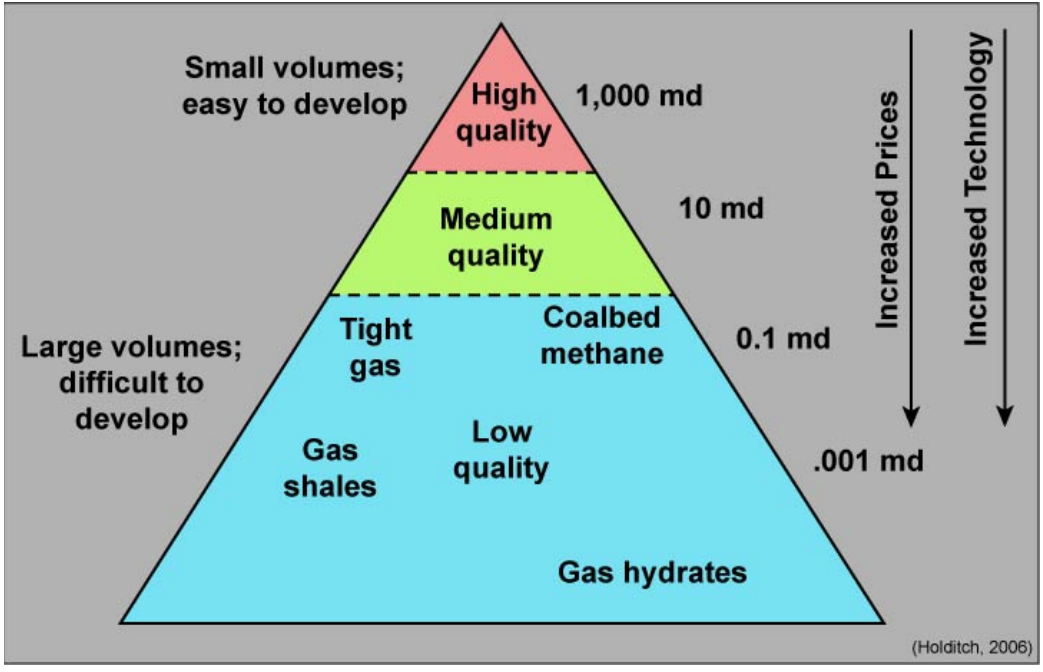

Figure A6. Resource triangle for natural gas (from Holditch, 2006).

\section{Shale Gas}

As an unconventional energy resource, shale gas has many similarities to coalbed methane. In fact, it is possible to have both methane-rich shales and coals interbedded in a single reservoir, resulting in production from both lithologies. About 1.0 Tscf (trillion standard cubic feet) of the nation's 2.7 Tscf of unconventional gas production comes from more than 40,000 shale gas wells in five primary basins (Jenkins and Boyer, 2008). Worldwide shale-gas resources are estimated to exceed 16,000 Tscf.

In conventional natural gas reservoirs, the gas has migrated from an organic-rich source rock into pore spaces between sand grains in the reservoir (refer to the section in this chapter on conventional oil and gas for more information). The source rocks are often black, organic-rich shales that have formed in sedimentary deposits given sufficient geologic time (generally millions or more years) and depth of burial. In unconventional shale gas reservoirs, the organic-rich shale is both the source rock and the reservoir. Shale gas can be generated through thermogenic or biogenic processes, and the geologic setting of the basin determines which process is operative. Shale gas source rocks are not as rich in carbon 


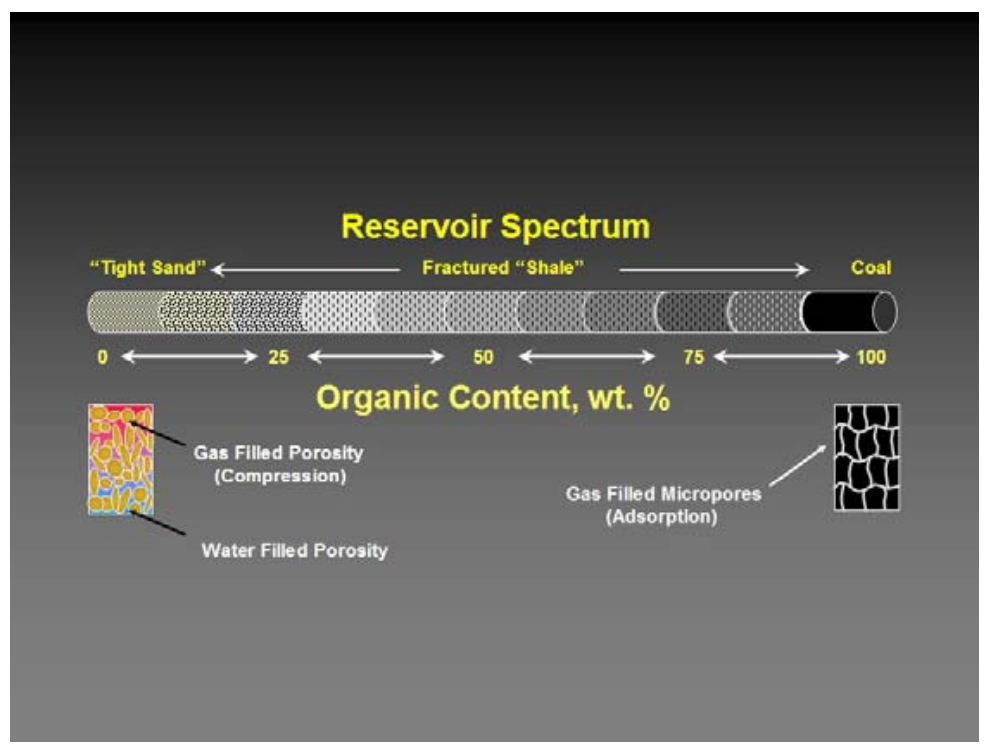

Figure A7. Comparison of organic contents of shales, coals, and tight sands (modified from Hartman, 2008).

as coals, and typically contain less than $50 \mathrm{wt} \%$ (weight percent) of organic matter (fig. A7). Once gas is generated in a shale source rock, some of the gas is stored in the rock's pore systems and some becomes attached to the surface of mineral particles comprising the shale in a process referred to as 'adsorption.' The latter gas is said to be adsorbed on the rock matrix. Refer to the sections describing the geologic requirements for exploitable conventional oil and gas, coal, and coalbed methane for more detailed explanations of source rocks, reservoir rocks, adsorption, and the conditions necessary to generate hydrocarbons.

Controls on resource volume and productivity in shale gas systems are similar to those in coalbed methane systems, however, the shale gas reservoirs are typically thicker (30 to 300 feet) and have a much larger volume of free gas in pore space and much lower adsorbed gas content (Jenkins and Boyer, 2008). Whereas coalbed methane reservoirs rely on naturally-occurring orthogonal fracture sets called cleats, shale gas plays have much lower permeabilities than coalbed reservoirs (typically in the nano- to microdarcy range) and rely heavily on induced hydraulic fracturing (stimulation) to connect natural fractures to the wellbore to become gas producers. While both tight gas and shale gas reservoirs may require 'fracking' to maximize production, due to the extremely low natural permeabilities of shales, a special type of fracking suitable for shales is required. A technique called 'slick-water frac' results in maximizing the horizontal length of fractures and minimizes the vertical fracture height, allowing for much greater gas recovery from shales (Harper, 2008).

As in most coalbed reservoirs, some shale-gas reservoirs are water-saturated, and require dewatering to initiate the flow of gas. As this water is produced from the natural and enhanced fracture system, the reservoir pressure declines, gas desorbs from the mineral matrix, and gas production increases. Shale gas production is similar to conventional gas reservoirs, with peak initial rates of production and slow decline thereafter as gas desorption replenishes the fracture system. As with coalbed methane, produced water must be disposed, and in Alaska's high-latitude setting this poses significant challenges.

Because shales ordinarily have insufficient permeability to allow significant fluid flow to a well bore, most shales are not commercial sources of natural gas in their natural state. Because of the low matrix permeability in shales, gas production in commercial quantities requires fractures to increase permeability. Shale gas has been produced for years from shales with natural fractures; the shale gas boom in recent years has resulted from modern technology in hydraulic fracturing to create extensive artificial fractures around well bores.

In summary, shale gas reservoirs are geologically complex and because of their very low permeability (typically $<0.1 \mathrm{md}$ ) these reservoirs require special techniques for evaluation and extraction. Thus, as in coalbed methane and tight gas reservoirs, detailed understanding of the geology of potential shale gas resource is essential.

\section{Gas Hydrate}

According to the U.S. Geological Survey, a gas hydrate is a naturally-occurring, ice-like solid in which water molecules trap gas molecules in a cage-like structure known as a 'clathrate' (fig. A8). A gas hydrate or clathrate is similar to ice, except that the crystalline structure is stabilized by the guest gas molecule in the cage of water molecules. Gas hydrates occur under a very limited range of temperature and pressure conditions, such as in the permafrost environments of the arctic, including northern Alaska. They also occur in deep marine environments at water depths greater than 400 or 500 meters ( 1,300 to 1,640 feet), along most continental margins. In these environments (arctic and deep ocean) gas hydrates occur naturally where pressure, temperature, gas saturation, and local chemical conditions combine to make them stable. Before gas hydrates can form, there must be a source for gas molecules. Potential sources include sedimentary rocks that are rich in carbon, such as some black shales, limestones, and coal. Peat is a precursor to coal and can also generate gas under the right conditions. Refer to the summary of the geologic requirements for conventional oil and gas, coal, and coalbed methane for more detailed explanations on the origins of gas.

Gas hydrates are currently considered to be a potentially vast, unconventional energy resource with the possibility 


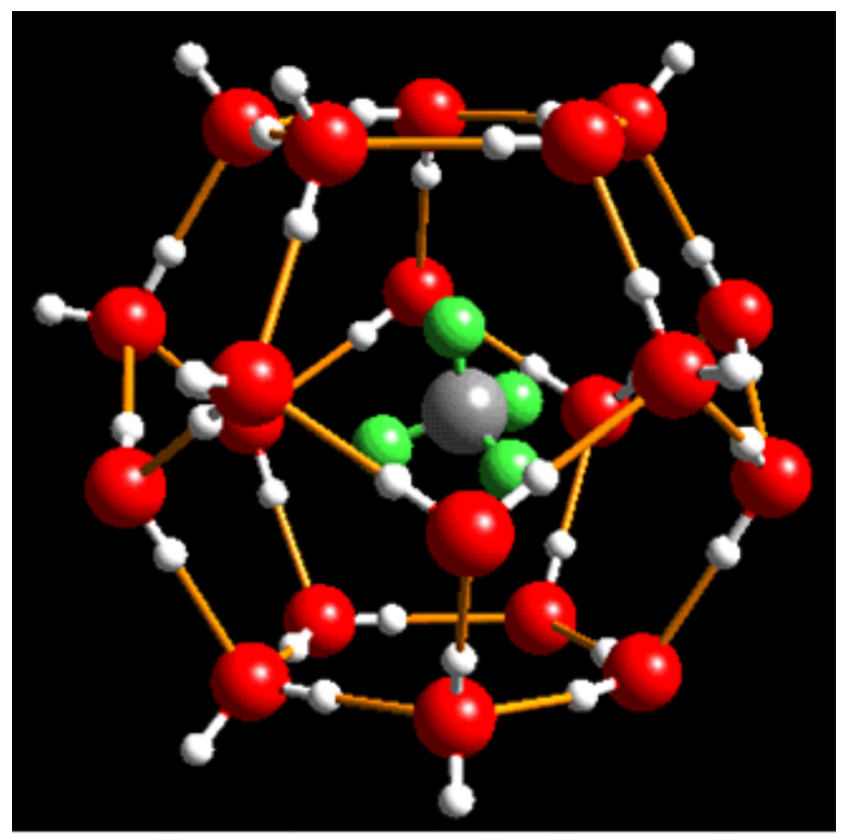

Figure A8. Gas hydrate or clathrate molecule, which consists of a methane molecule (gray and green) surrounded by a cage-like structure of ice (red and white). From Centre for Gas Hydrate Research: http://peggy.uni-mki.gwdg. de/docs/kuhs/clathrate_hydrates.html

for viable production sometime in the future. However, gas hydrates present both scientific and technological challenges in turning them from non-producible accumulations of gas to a useable resource (Collett, 2004). Gas production from hydrates is challenging because the gas is in a solid form, and because hydrates are widely dispersed in hostile Arctic and deep marine environments. Methods proposed for gas recovery from hydrates typically deal with disassociating or "melting" in-situ gas hydrates, by heating the reservoir beyond the temperature of hydrate formation or decreasing the reservoir pressure below hydrate equilibrium. "Depressurization is considered to be the most economically promising method for the production of natural gas from gas hydrates. The Messoyakha gas field in northern Russia is commonly used as an example of a hydrocarbon accumulation from which gas has been produced from hydrates by simple reservoir depressurization. The field was developed for conventional gas, and scientists have long thought that the sustained gas production was because of the contribution of gas from gas hydrate into an underlying free-gas accumulation" (Collett, 2004). Experimental gas production rates reported from recent gas hydrate testing at the Canadian Mallik site compare favorably with the modeled production rates predicted for the gas hydrate occurrences in northern Alaska (Anderson and others, 2008).

In 1995, the USGS conducted an assessment of the gas hydrates in the United States and Alaska (Collett, 1995) and in 2008 they released an assessment of undiscovered, technically recoverable gas hydrate resources beneath the North Slope of Alaska (Collett and others, 2008; Lee and others, 2008). The factors controlling gas hydrate formation, mostly a function of formation temperature and pressure, were assessed to map the spatial distribution of the gas hydrate stability zone in northern Alaska. Only gas hydrates lying below the permafrost interval were assessed, limiting the assessment to the stratigraphic interval below the base of the permafrost and above the base of the gas hydrate stability zone. The USGS estimates that the total undiscovered natural gas resources in gas hydrate range between 25.2 and 157.8 trillion cubic feet (TCF; 95 percent and 5 percent probabilities of greater than these amounts, respectively), with a mean estimate of 85.4 TCF (Collett and others, 2008). Outside of the North Slope region, there are likely no onshore gas hydrates in Alaska.

\section{Underground Coal Gasification}

Underground coal gasification (UCG) is a technology that utilizes the in situ burning of deep, unmineable coal seams to generate a synthetic gas (syngas) mixture. The combustion of coal seams at depth involves the introduction of water (preferably steam) and oxygen from the surface through an injection well. The syngas is a mixture of hydrogen $\left(\mathrm{H}_{2}\right)$, nitrogen $\left(\mathrm{N}_{2}\right)$, methane $\left(\mathrm{CH}_{4}\right)$, carbon monoxide $(\mathrm{CO})$, and carbon dioxide $\left(\mathrm{CO}_{2}\right)$ that is brought to the surface through a production well and used to generate electricity in gas turbines at an electrical power plant (Burton and others, 2007) (fig. A9). The basic reaction to create syngas is $\mathrm{C}+\mathrm{H}_{2} \mathrm{O}+$ heat $\rightarrow \mathrm{CO}+\mathrm{H}_{2}$. The syngas can also be converted into a variety of hydrocarbons, such as diesel fuel, naphtha, and methane using the Fischer-Tropsch process.

The technology to generate syngas from coal has existed for more than a century, and the Yerostigaz plant in Angren, Uzbekistan has been generating 100 megawatts of electricity annually since 1957 using UCG methods. Currently, a number of experimental UCG plants have been constructed and several more are in the planning stages worldwide. The Cook Inlet region of Alaska is being evaluated for UCG potential.

The coal used in the UCG process can be lignite, subbituminous, or bituminous, and coal seams should be at least 10 feet thick. The life of the reaction chamber used for coal combustion increases with coal seam thickness. This reaction chamber cavity should be well below the water table, deeper than 500 feet-depths greater than 1,000 feet are preferred. Additionally, the surrounding rock strata should provide isolation from any aquifers that might be used as domestic water supplies. Strata above and below the coal seam should be structurally competent, and have low permeability.

Underground gasification of coal eliminates the need to mine and transport the coal to a power plant, as well as the costs associated with reclaiming the surface-mined coal areas. Additionally, the ash produced by conventional burning is 


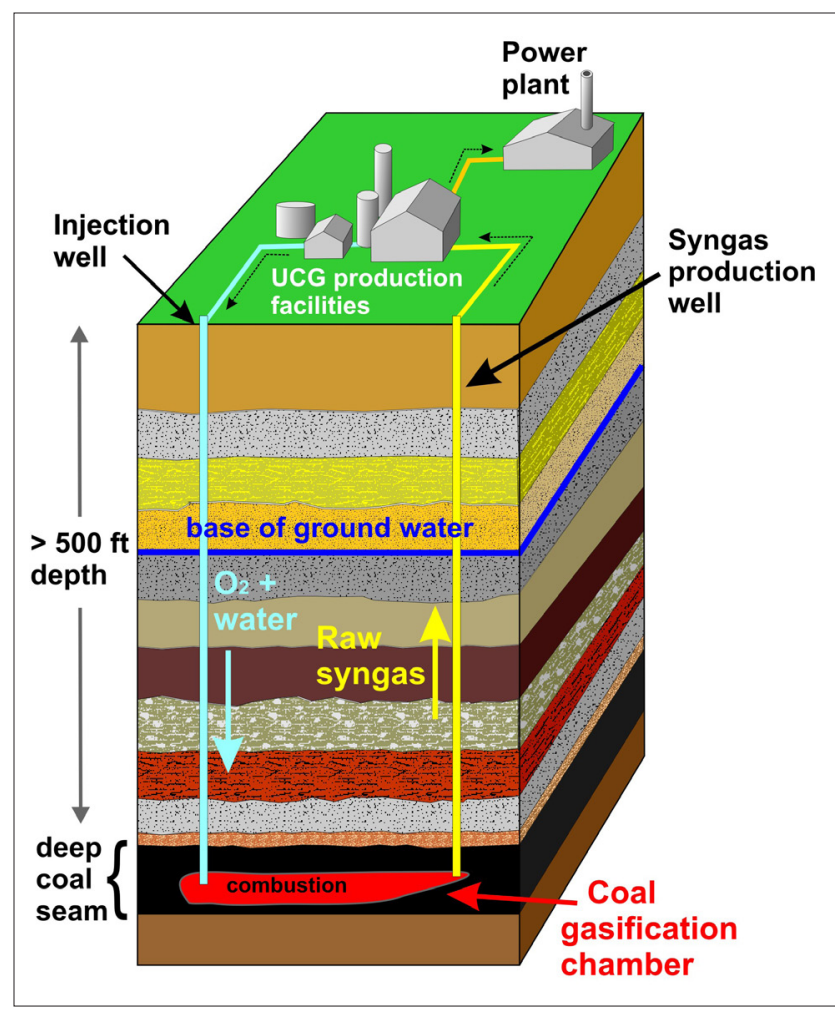

Figure A9. Conceptual model for underground coal gasification of deep, unmineable coal seams. Based on Swan Hills Synfuels in-situ coal gasification diagram, http://swanhills-synfuels.com

left in the ground and most of the heavy metals associated with the ash, such as mercury, arsenic, or lead, also stay in the ground. Many other undesirable reaction products, such as sulfur dioxide $\left(\mathrm{SO}_{2}\right)$ and nitrous oxide $\left(\mathrm{NO}_{\mathrm{x}}\right)$ are greatly reduced as well. The process of UCG can also be coupled with carbon capture and storage technology to reduce $\mathrm{CO}_{2}$ emissions. The advantages of using deep, unmineable coal seams are that they are less likely to be linked with nearsurface potable aquifers, thus avoiding drinkable water contamination and ground subsidence problems.

The underground coal gasification process creates a variety of engineering, data-gathering, monitoring, and environmental challenges. Among the engineering problems, developing effective dispersal of oxygen and combustion within the coal seam, and creating an effective connection between the combustion zone and the production wells can be major challenges. Supplying the right amount of oxygen to maintain optimal combustion and reaction activity, and to keep the reactor chamber at the desired temperature and pressure, can also be problematic. Continuous monitoring of aquifers for the potential for groundwater contamination is also necessary. Additionally, there exists the potential for surface subsidence due to collapse of the subsurface combustion chamber.

\section{GEOLOGIC REQUIREMENTS FOR A GEOTHERMAL ENERGY RESOURCE}

\author{
by Christopher J. Nye
}

Geothermal is a general term describing the heat generated and contained within the earth. Although more than 90 percent of the total volume of the earth is warmer than $1,000^{\circ} \mathrm{F}\left(540^{\circ} \mathrm{C}\right)$, only a small amount of this potential energy makes it close enough to the earth's surface to be utilized by conventional technology and considered an energy resource. When it does, the elevated heat manifests itself in a number of uncommon geologic occurrences such as lava flows and volcanic eruptions, steam vents or geysers, hot springs, or merely elevated geothermal gradients creating hot rock. In normal geologic situations the majority of the heat simply slowly dissipates into the atmosphere from forests, prairies, and backyards in an unseen process known as 'conduction.' At the surface of the earth, heat can also be gained from the sun during daylight hours, and especially during the summer months, to depths as great as 100 feet. When ground source heat pumps, which utilize pipes laid out a few feet below the surface, are used installed for heating or cooling buildings, the process can use either solar or geothermal energy. Below a depth of a several tens of feet any heat recovered from the earth will usually be geothermal in origin. Geothermal heat comes from two main sources - the original heat of the earth generated at its formation about 4.5 billion years ago, and more recent decay of the radioactive isotopes of potassium, uranium, and thorium.

Geothermal resources are found on all continents and have been used for a wide variety of purposes. For large-scale (measured in megawatts or millions of watts) electrical power generation, temperatures from about $300^{\circ} \mathrm{F}\left(150^{\circ} \mathrm{C}\right)$ to as high as $650^{\circ} \mathrm{F}\left(340^{\circ} \mathrm{C}\right)$ are typically needed. In Alaska, however, with its cold climate and abundant cold water resources, it is possible to exploit much lower geothermal temperatures for small-scale electrical power generation. In fact, at Chena Hot Springs Resort near Fairbanks, 500 gallons per minute of water with a temperature of $163^{\circ} \mathrm{F}\left(72.8^{\circ} \mathrm{C}\right)$ is currently making around $200 \mathrm{~kW}$ (kilowatts) of electricity, which is the amount of electricity used by a village of about 300 residents. The combination of high flow rates of hot water and low surface water temperatures available at Chena allow it to be the lowest-temperature geothermal power plant in the world.

For geothermal energy to be technically and economically feasible a number of conditions must be met. These include: (1) an anomalous thermal gradient or accessible heat in a near-surface region, (2) sufficient porosity and permeability within the section of 'hot rock' so fluids can move freely and transfer heat, and (3) some form of conduit that allows a hot fluid to flow to the surface in sufficient quantities where the energy is converted into a usable form. Clearly, the higher the near-surface temperature, and higher the permeability and flow rates, the more feasible the resource becomes. 
Unfortunately, out of the thousands of natural springs in Alaska, only a very few have sufficient temperature and flow rates needed to produce enough electricity to export power from the plant. In some limited cases where high near-surface heat exists, these fluid flow and heat transfer systems can be enhanced by drilling and fracture technology if the geologic conditions are right.

Most of the Earth is not near volcanoes or close to major active faults and therefore lacks open space or fractures that can heat fluids, which are necessary for a shallow geothermal system. In these areas enhanced systems must be created. However, the geothermal industry has long known that developable heat exists within drillable depths in most areas of the globe, yet a technically feasible way to transfer that heat to the surface in economic quantities has been very elusive. If this methodology can be developed, it has the potential to access a tremendous energy resource. One interesting development in this research effort is the use of techniques devised by the oil and gas industry to fracture rocks far below the surface by pumping huge volumes of fluid at very high pressure into the deep strata. The theory contends that once the rocks are broken and permeability established, it is possible to pump cold water down one hole into hot rocks and recover it from a second hole thousands of feet away.

If a sufficient network of interconnected fractures can be created at great depths, and hydraulic connection can be established between distant well bores, the water will 'mine' heat from the fracture surfaces between the two holes and become hot enough for direct use and/or electrical power generation. For these types of "enhanced geothermal systems" (EGS) to work, a number of geologic and physical attributes must be present, including brittle stratigraphy and an existing stress regime that is conducive to fracture propagation of sufficient length and orientation.

There has been a wide variance in outcomes from pilot EGS programs, often related to the wide variability of sub-surface geology. Despite many failures, there are some promising experiments underway in France, Germany, and Austria where six small projects are generating between 0.25 and 3.5 megawatts of electrical power from wells between 7,000 and 16,000 feet deep and at temperatures from $206^{\circ} \mathrm{F}$ $\left(97^{\circ} \mathrm{C}\right)$ to $250^{\circ} \mathrm{F}\left(121^{\circ} \mathrm{C}\right)$. A major challenge for any lowtemperature application is whether there is enough power generated to run all of the equipment and pumps used in the operation and send the excess offsite. After the power is generated, additional heat is removed from the water for space heating as a part of some of the projects. These European projects have all been expensive, governmentsupported research projects to date and have taken many years to develop; but with this experience in hand, plans have recently been announced for more than 100 future projects in Germany alone, with outputs as high as 8.5 megawatts for individual projects. In Australia, numerous press releases are touting much higher potential electrical outputs, but no projects are yet on line. Development of enhanced geothermal systems will continue to be a mostly experimental program for the next several years, but bears close scrutiny because there may come a time when it could be used in Alaska where local geologic conditions are favorable.

\section{REFERENCES CITED AND SELECTED BIBLIOGRAPHY}

American Society of Testing Materials (ASTM), 1983, Standard classification of coal by rank-ASTM designation D388-82 in gaseous fuels, coal and coke: Philadelphia, 1983 Book of Standards, v. 5.05.

1995, Standard classification of coal by rank-ASTM designation D388-82: Philadelphia, 1995 Book of Standards, v. 5.05, p. 168-171.

Anderson, B.J., Wilder, J.W., Kurihara, Masanori, White, M.D., Moridis, G.J., Wilson, S.J., Pooladi-Darvish, M., Masuda, Y., Collett, T.S., Hunter, R.B., Narita, H., Rose, K., and Boswell, Ray, 2008, Analysis of modular dynamic formation test results from the Mount Elbert 01 stratigraphic test well, Milne Point Unit, North Slope Alaska: Proceedings of the 6th International Conference on Gas Hydrates (ICGH 2008), July 6-10, 2008, Vancouver, British Columbia, Canada, 13 p. (on CD-ROM).

Ayers, W.B., Jr., 2002, Coalbed gas systems, resources and production and a review of contrasting cases from the San Juan and Powder River basins, in Law, B.E., and Curtis, J.B., eds., Unconventional Petroleum Systems: AAPG Bulletin, v. 86, no. 11, p. 1,853-1,890.

Bowen, B.H., and Irwin, M.W., 2008, Coal Characteristics, CCTR Basic Facts File \#8, Purdue University, http:// www.purdue.edu/discoverypark/energy/assets/pdfs/ cctr/outreach/Basics8-CoalCharacteristics-Oct08.pdf

Burton, Elizabeth, Friedmann, Julio, Upadhye, Ravi, 2007, Best practices in underground coal gasification; Technical report: Livermore, California, Lawrence Livermore National Lab, 119 p.

Bustin, R.M., and Clarkson, C.R., 1998, Geological controls on coalbed methane reservoir capacity and gas content: International Journal of Coal Geology, v. 38, no. 1-2, p. 3-26.

Collett, T.S., 1995, Gas hydrate resources of the United States, in Gautier, D.L., Dolton, G.L., Takahashi, K.I., and Varnes, K.L., eds., 1995 National assessment of United States oil and gas resources - Results, methodology, and supporting data: U.S. Geological Survey Digital Data Series 30 (on CD-ROM).

2004, Gas hydrates as a future energy resource: Geotimes, v. 49, no. 11, p. 24-27.

Collett, T.S., Agena, W.F., Lee, M.W., Zyrianova, M.V., Bird, K.J., Charpentier, R.R., Cook, Troy, Houseknecht, D.W., Klett, T.R., Pollastro, R.M., and Schenk, C.J., 2008, Assessment of gas hydrate resources on the North Slope, 
Alaska, 2008: U.S. Geological Survey Fact Sheet 20083073, 4 p. http://pubs.usgs.gov/fs/2008/3073/

Curtis, J.B., 2002, Fractured shale-gas systems: AAPG Bulletin, v. 85 , no. 11, p. $1,921-1,938$.

Harper, J.A., 2008, The Marcellus Shale_An old "new” gas reservoir in Pennsylvania: Middletown, Pennsylvania Geology, Bureau of Topographic and Geologic Survey, Pennsylvania Department of Conservation and Natural Resources, v. 38, no. 1, p. 2-13.

Hartman, Chad, 2004, Shale gas core analyses required for gas reserve estimates: Presentation at October 2008 Society of Petroleum Engineers Fort Worth Section's Panel Discussion, Barnett Shale Reserves---The Evolution, http://ftworth.spe.org/article.cfm?id=84.

Hartman, R.C., Lasswell, Pat, and Bhatta, Nimesh, 2008, Recent advances in the analytical methods used for shale gas reservoir gas-in-place assessment: Search and Discovery article \#40317, posted October 30, 2008, http://www.searchanddiscovery.com/ documents/2008/08209hartman/index.html

Holditch, S.A, 2006, Tight gas sands: Society of Petroleum Engineers Distinguished Author Series, paper SPE 103356, p. 86-93.

Jenkins, C., and Boyer II, C.M, 2008, Coalbed- and shale-gas reservoirs: Society of Petroleum Engineers Distinguished Author Series, paper SPE 103514, p. 92-99.

Kentucky Geological Survey, 2006, How is coal formed?: Kentucky Geological Survey, University of Kentucky, http://www.uky.edu/KGS/coal/coalform.htm

Lee, M.W., Collett, T.S., and Agena, W.F., 2008, Assessing gas-hydrate prospects on the North Slope of AlaskaTheoretical considerations: U.S. Geological Survey, Scientific Investigations Report 2008-5175, 28 p.

Magoon, L.B., III, and Dow, W.G., 1994, The petroleum system, in Magoon, L.B., III, and Dow, W.G, eds., The Petroleum System-From Source to Trap: AAPG Memoir 60, p. 3-24.

Merritt, R.D., and Hawley, C.C., 1986, Map of Alaska's coal resources: Alaska Division of Geological \& Geophysical Surveys Special Report 37, 1 sheet, scale 1:2,500,000.

Naik, G.C., 2007, Tight gas reservoirs-An unconventional natural energy source for the future: Sublette County, Wyoming municipal government website, Documents and Datasets: Gas Field Documents, www.sublette-se. org/files/tight_gas.pdf, $32 \mathrm{p}$.

Ogbe, D.O., Clough, J.G., Patil, S.L., and Reynolds, Doug, 2006, Rural Alaska coalbed methane: Application of new technologies to explore and produce energy: National Energy Technology Laboratory, Arctic Energy Office, U.S. Department of Energy, final report of work performed for grant DE-FC26-01NT41248, 123 p., http://www.osti. gov/bridge/servlets/purl/899159-xjCWSd/899159.pdf
Saulsberry, J.L., Schafer, P.S., and Schraufnagel, R.A., eds., 1996, A guide to coalbed methane reservoir engineering: Chicago, Illinois, Gas Research Institute Report GRI94/0397, 342 pages.

Schraufnagel, R.A., 1993, Coalbed methane production, in Law, B.E., and Rice, D.D., eds., Hydrocarbons from coal: AAPG studies in Geology v. 38, p. 341-359.

Scott, A.R., 1995, Application of burial history and coalification to coalbed methane producibility, in Kaiser, W.R., Scott, A.R., and Tyler, R., eds., Geology and Hydrology of Coalbed Methane Producibility in the United StatesAnalogs for the World: InterGas '95, The University of Alabama Continuing Education Workshop, p. 127-136.

1999, Improving coal gas recovery with microbially enhanced coalbed methane, in Mastalerz, M., Miryam, G.M., and Golding, S.D., eds., Coalbed methane; Scientific, environmental, and economic evaluation: Dordrecht, Boston, London, Kulwer Academic Publishers, p. 89-110.

2004, Coal gas origins and exploration strategies: Short course presentation at Mid-Continent Coalbed Methane Symposium, November 7-9, 2004, Tulsa, Oklahoma. Presentation accessed 8-15-12 at http://www.kgs. ku.edu/PTTC/Case_Studies/CBMconf/E_Scott2004.pdf

Stach, E., Mackowsky, M-Th., Teichmüller, M., Taylor, G.H., Chandra, D., and Teichmüller, R., 1975, Stach's textbook for coal petrology (2nd ed.): Berlin, Stuttgart, Gebruder Borntraeger, $428 \mathrm{p}$.

Wood, G.H., Jr., Kehn, T.M., Carter, M.D., and Culbertson, W.C., 1983, Coal resource classification system of the U.S. Geological Survey: U.S. Geological Survey Circular 891, 65 p. http://pubs.usgs.gov/circ/c891/ 